\title{
REVIEW
}

\section{The Role of Bile in the Regulation of Exocrine Pancreatic Secretion}

As early as 1926 Mellanby (1) was able to show that introduction of bile into the duodenum of anesthetized cats produces a copious flow of pancreatic juice. In conscious dogs, Ivy \& Lueth (2) reported, bile is only a weak stimulant of pancreatic secretion. Diversion of bile from the duodenum, however, did not influence pancreatic volume secretion stimulated by a meal $(3,4)$. Moreover, Thomas \& Crider (5) observed that bile not only failed to stimulate the secretion of pancreatic juice but also abolished the pancreatic response to intraduodenally administered peptone or soap.

In man, the first report of a stimulating action of bile on pancreatic secretion was that of a patient with complete neoplastic obstruction of the common bile duct, published in 1942 by Lagerlöf (6). Intraduodenal application of cattle bile increased pancreatic volume and bicarbonate secretion, whereas enzyme secretion was not influenced. It was not until the sixties that Forell et al. $(7,8)$ rediscovered bile and bile salts as stimulants of exocrine pancreatic secretion in humans. After these first systematic studies, several investigators confirmed the stimulatory effect of bile and bile saits on exocrine pancreatic secretion (for example, Refs. 9-11), whereas others found no effect or even an inhibitory action (for example, Refs. 12, 13).

In this review we would like to put forward the hypothesis that these controversial results may be primarily due to different experimental conditions. Several studies have been used with regard to the effect of intraduodenal bile and bile salts on basal or on exogenously stimulated pancreatic secretion by secretin or by secretin and cholecystokinin (CCK). Others have been performed on the endogenously stimulated pancreas by means of intestinally applied nutrient compounds probably interfering with the action of bile and bile salts. Diversion of bile and oral or intraduodenal application of bile-salt-binding resins (such as cholestyramine) may also provide approaches to study the role of bile and bile salts in the regulation of exocrine pancreatic secretion.

\section{Effect of bile and bile salts on basal and hormonally stimulated} pancreatic secretion

Evaluating pancreatic function tests with secretin in man, Forell et al. (7) observed a lower secretion rate of trypsin, lipase, amylase, bicarbonate, and fluid in patients without simultaneous gallbladder contraction. This diminished

Dedicated to Professor M. M. Forell on the occasion of his 75th birthday. response could be restored by intraduodenal application of human gallbladder bile and by gallbladder emptying induced by an extract of the neurohypophysis (Hypophysin ${ }^{\circledR}$ ). Moreover, in cholecystectomized patients - with a continuous bile flow into the duodenum - trypsin secretion was significantly higher than in healthy controls with bile-free duodenal aspirates (14). Furthermore, the initial pancreatic response to secretin and CCK was significantly reduced in cholecystectomized patients $(15,16)$. This effect could also be restored by intraduodenal application of exogenous bile. Hence, Forell and co-workers concluded that the presence of bile in the duodenum may stimulate the ecbolic and hydrokinetic pancreatic function. Subsequently, they performed more systematic studies of the intraduodenal action of bile on the exocrine pancreas in man.

Intraduodenal application of 2,4 , and $6 \mathrm{~g}$ of dried cattle bile, dissolved in $20 \mathrm{ml}$ of water, induced a dose-dependent increase of basal pancreatic trypsin, lipase, amylase, bicarbonate, and volume secretion $(14,17)$. Under these conditions, $6 \mathrm{~g}$ of bile proved to be as potent as a combined

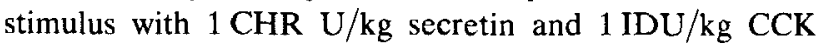
intravenously (17). The amount of bile applied was comparable to that of a full gallbladder (18). The hydrokinetic and ecbolic effect of intraduodenally applied bile on basal and on hormonally stimulated pancreatic secretion could be confirmed in man by several investigators $(10,19-23)$. Moreover, a clear-cut dose-response relationship of intraduodenal bile on pancreatic volume, bicarbonate, and enzyme secretion during a secretin background infusion (11) and under basal conditions (24) could be established. The hydrokinetic effect of $6 \mathrm{~g}$ of cattle bile corresponded to an intravenous dose of $0.25 \mathrm{CU} / \mathrm{kg}$ of secretin, whereas the ecbolic effect of bile was significantly higher (11). Resembling the permanent bile flow in cholecystectomized patients, continuous intraduodenal infusion of $0.15 \mathrm{~g}$ bile $/ \mathrm{min}$ enhanced volume and bicarbonate secretion and, to a lesser extent, protein output, as Osnes \& Hanssen could show (22).

In animals, however, contradictory results have been reported with regard to the effect of intraduodenal bile on basal pancreatic secretion, as mentioned above. In conscious dogs intraduodenal application of bile had either no effect on pancreatic volume, bicarbonate, and protein secretion (25) or caused a marked increase of protein secretion and, to a lesser extent, of volume and bicarbonate output (26).

Bile salts are assumed to be the effective constituents of 
bile in man and animals. Species differences, however, may exist with regard to the relative potencies of the individual bile salts. In man, duodenal concentrations of bile salts vary from 0.1 to $4.0 \mathrm{mmol} / \mathrm{l}$ in the interdigestive state and from 0.1 to $39.6 \mathrm{mmol} / 1$ after a meal $(27,28)$. In total amounts, maximally 5 to $7.5 \mathrm{~g}$ (10 to $15 \mathrm{mmol}$ ) of bile salts are excreted postprandially (29).

Wormsley (9) was able to show in man that a rapid ( $2 \mathrm{~min}$ ) intraduodenal injection of a mixture of several bile salts $(6 \mathrm{~g}$ dissolved in $20 \mathrm{ml}$ of water) and a continuous infusion of this solution $(6 \mathrm{~g} / 10 \mathrm{~min})$ elicited a marked stimulation of pancreatic enzyme, volume, and bicarbonate secretion. Moreover, Forell et al. $(8,14)$ demonstrated during a constant secretin infusion that the pure bile salts Na-glycocholate and $\mathrm{Na}$-glycodehydrocholate $(10 \mathrm{ml}$ of a 120 -mmolar solution) produced a slight re in volume and bicarbonate and a marked rise in trypsin secretion, whereas glycocholic acid-insoluble in neutral water-had no effect.

Intraduodenal application of 0.37 to $1.11 \mathrm{mmol}$ of $\mathrm{Na}$ taurocholate caused only a weak and dose-independent hydrokinetic effect and nearly no ecbolic effect on secretinstimulated pancreatic secretion (11). By means of a duodenal perfusion technique Na-taurocholate $(10 \mathrm{ml} / \mathrm{min}$ of a 10 mmolar solutionj slightly increased basal, but not secretin/ceruletide-stimulated, trypsin secretion $(12,30$, 31). Basal bicarbonate secretion remained unchanged and secretin-stimulated bicarbonate secretion was slightly increased (30). Holtermüller et al. (32), however, were not able to demonstrate any effect of Na-taurocholate on secretin/ceruletide-stimulated pancreatic secretion.

In contrast, the dihydroxy bile salt Na-taurodeoxycholate dose-dependently $(0.38$ to $1.14 \mathrm{mmol})$ enhanced basal (24) and secretin-stimulated (11) volume, bicarbonate, and enzyme secretion. The effect was related to the load, not to the concentration of this bile salt (11). Na-taurodeoxycholate was almost as potent as total bile both on basal (24) and on secretin-stimulated (11) pancreatic secretion. It is noteworthy that the amounts of $\mathrm{Na}$-taurodeoxycholate applied in these studies corresponded to those injected with total bile. Chenodeoxycholate, another dihydroxy bile salt, infused into the duodenum at a concentration of $50 \mathrm{mmol} /$ 1 also markedly increased basal bicarbonate and trypsin secretion (33). Comparable results were obtained after intraduodenal application of $0.8 \mathrm{mmol}$ chenodeoxycholate during a secretin background infusion (34).

In animals bile salts also proved to be the effective constituents of bile in stimulating basal and secretin-induced pancreatic secretion. In anesthetized cats an increase of volume and bicarbonate secretion was observed during intraduodenal perfusion with Na-taurocholate under basal conditions (35) and during a constant secretin background infusion $(36,37)$, whereas pancreatic enzyme output was sparsc. Similar results were also obtained with Na-ursodeoxycholate, a metabolite of Na-chenodeoxycholate (37). Furthermore, Hanssen et al. (36) showed a dose-response relationship of $\mathrm{Na}$-taurocholate, the predominant bile salt $(89.6 \%)$ in cat gallbladder bile (38), with regard to pancreatic volume secretion. The threshold concentration of 5 to $6 \mathrm{mmol} / \mathrm{l}$ is within the physiologic range found in the duodenum of the cat. By contrast, in conscious dogs intraduodenal infusion of Na-taurocholate $(5 \mathrm{mM}$ and $12 \mathrm{mM}$, respectively) significantly increased not only basal volume and bicarbonate secretion but, most pronounced, also protein output $(26,39)$.

In anesthetized rabbits, however, no effect of intraduodenally infused Na-cholate, Na-deoxycholate, Nachenodeoxycholate, and Na-tauroursodeoxycholate was observed on basal pancreatic secretion $(40,41)$. The only exception was Na-ursodeoxycholate $(0.12$ and $0.24 \mathrm{mmol} /$ $\mathrm{kg} \cdot 30 \mathrm{~min}$ ), significantly enhancing pancreatic flow and bicarbonate output. The increase of protein output, however, was only transient (40). In anesthetized pigs, a very high dose of a mixture of bile salts $(100 \mathrm{mg} / \mathrm{kg})$ induced an increase of secretin-stimulated volume secretion, whereas lipase output was only weak and short-lasting (42). Results observed in rats will be discussed below. The inconsistent results about the efficacy of single bile salts may be partially explained by species differences, by the load and kind of bile salt application, and by anesthesia. The latter is known to influence the autonomic nervous system, probably being one of the mediators of bile salts (43).

Replacement of taurine by glycine in deoxycholate did not influence the marked stimulatory effect of this bile salt on exocrine pancreatic secretion in man (44), suggesting that the active site is confined to the basal structure of the cholanic acid and the state of hydroxylation. This supposition is supported by studies in man by Forell et al. (8). The authors were able to show a pronounced stimulation of exocrine pancreatic secretion by the unconjugated $\mathrm{Na}$-deoxycholate as well. In contrast, in anesthetized rabbits the taurine conjugate of $\mathrm{Na}$-ursodeoxycholate was ineffective, whereas the unconjugated bile salt enhanced volume, bicarbonate, and protein secretion. With deoxycholate, however, no stimulatory effect was observed at all, both when applied in the conjugated and in the unconjugated form (40). These contradictory results may be at least partly due to species differences.

The action of bile salts appears to be restricted to their solubility, since pure glycocholic acid, scarcely soluble in water $\left(0.33 \mathrm{~g} / 1 \mathrm{H}_{2} \mathrm{O}\right)$, was ineffective, whereas Na-glycocholate (solubility, $275 \mathrm{~g} / \mathrm{l} \mathrm{H} \mathrm{H}_{2} \mathrm{O}$ ) enhanced hydrokinetic and, more distinctly, enzyme secretion in man (8). Mellanby (1) has already noted that cholic acid, hardly soluble in water, produces only a very weak increase of pancreatic flow as compared with $\mathrm{Na}$-glycocholate and $\mathrm{Na}$-taurocholate.

Enzyme activation by bile or bile salts was excluded by in vitro studies (8). An influence of the osmolarity of the solutions applied is also unlikely, since hypertonic solutions of glucose and mannitol left pancreatic secretion unchanged $(8,14)$. In most of the studies, the $\mathrm{pH}$ of bile and bile 
salt solutions used was in the neutral range ( $\mathrm{pH} 6$ to 8 ). Therefore, the stimulatory action cannot be referred to the acidity of these solutions (45). The effect of bile salts is also not due to the detergency of these molecules $(25,37)$; furthermore, it is related to the load, not to the concentration of bile salts applied (11). Moreover, the dose-response relationship observed, at least in man, and the different potencies of single bile salts in stimulating hydrokinetic and ecbolic pancreatic secretion also fail to support an unspecific action of bile salts. A role of calcium as an effective principle of total bile could be ruled out as well, because the amount of calcium contained in bile is too low (46).

In contrast to intraduodenal administration, intrajejunal application of bile showed only a small augmentation of volume and bicarbonate secretion and no changes of enzyme output during a constant secretin infusion in man (47). Perfusing the upper jejunum of the cat, Hartmann et al. (35) concordantly observed a significantly lower pancreatic response to Na-taurocholate than after duodenal perfusion. Perfusion of the ileum was without effect. In dogs, however, infusion of bile into the duodenum and the jejunum caused an identical increase of exocrine pancreatic secretion (26), whereas infusion into the ileum showed no effect (26) or even inhibited secretin-stimulated pancreatic secretion (48). With regard to these few studies, the effect of bile and bile salts on exocrine pancreatic secretion seems to be primarily confined to the duodenum.

In summary, bile either endogenously released from the gallbladder or exogenously administered into the duodenum dose-dependently stimulates basal and secretin-induced hydrokinetic and ecbolic pancreatic secretion, at least in man. Bile salts are the effective constituents of bile, but there are differences in the efficacy of individual bile salts, which may also be species-specific. The action of bile salts is not influenced by the type of conjugation and cannot be referred to their role as detergents or to the $\mathrm{pH}$ of the solutions applied. The effect of bile and bile salts is predominantly restricted to the duodenum.

Effect of bile and bile salts on pancreatic secretion stimulated by intestinal nutrient compounds

In man, Malagelada et al. (12) showed that perfusion of the duodenum or the jejunum with essential amino acids or monoolein caused a significant increase of pancreatic trypsin and lipase output, but addition of Na-taurocholate, Nataurochenodeoxycholate, or Na-taurodeoxycholate in a concentration of $10 \mathrm{mmol} / 1$ to either stimulant significantly reduced the pancreatic response. The inhibitory action of bile salts was considered to be intraluminal, since bile salts did not modify the effects of cholecystokinin. Moreover, pancreatic secretion induced by intraduodenal perfusion with digestive products was not influenced by simultaneous intrajejunal infusion of bile salts. Raising the duodenal concentration of Na-taurocholate to the critical micellar concentration decreased the magnitude of the pancreatic
Table I. Effect of intraduodenal bile or bile salts on exocrine pancreatic secretion with regard to species investigated and experimental conditions established*

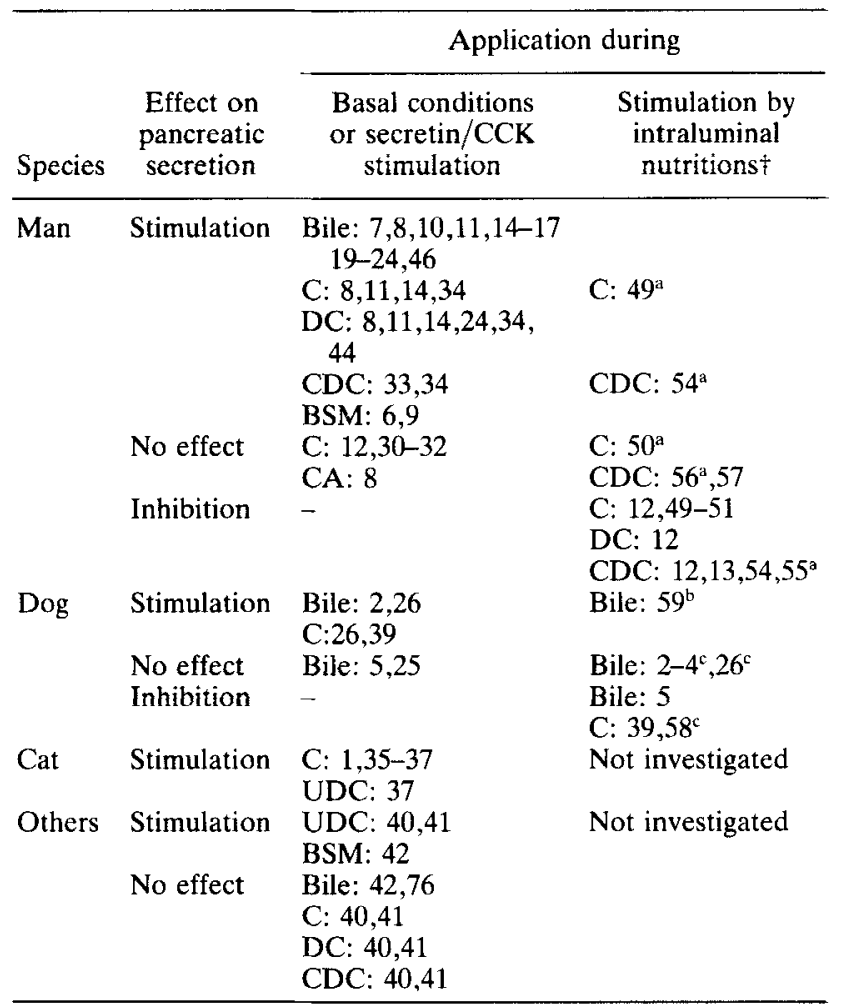

$\mathrm{CCK}=$ cholecystokinin; $\mathrm{C}=$ cholate $\mathrm{CA}=$ cholic acid $\mathrm{DC}=$ deoxycholate; $\mathrm{CDC}=$ chenodeoxycholate; $\mathrm{UDC}=$ ursodeoxycholate; $\mathrm{BSM}=$ mixture of bile salts

* Studies on rats have been excluded (see text); numbers indicate references.

$\dagger \mathrm{a}=$ High concentration; $\mathrm{b}=$ reintroduction during intragastric application; $c=$ reintroduction during intraduodenal application.

response to fatty acids but accelerated fatty acid absorption rates. A higher Na-taurocholate concentration $(20 \mathrm{mmol} / \mathrm{l})$, however-clearly beyond that necessary to form micellesexerted the opposite effect (increasing pancreatic response to reference values and slowing fatty acid absorption) $(49,50)$. In contrast, absorption rates of phenylalanine infused into the duodenum of volunteers were not altered by addition of $20 \mathrm{mmol} / \mathrm{l} \mathrm{Na-taurocholate,} \mathrm{but} \mathrm{pancreatic}$ secretion was markedly decreased (51). Intrajejunal perfusion of Na-taurocholate, however, did not influence phenylalanine-induced enzyme output, suggesting a segmental (duodenal) inhibition of luminally stimulated pancreatic secretion by bile salts $(51,52)$. Equimolar doses of phenylalanine and Na-taurodeoxycholate applied intraduodenally during a secretin background infusion in man caused a nearly equipotent ecbolic effect, whereas the hydrokinetic response was significantly higher after bile salt instillation. Combined application, however, showed a decreasing tendency of enzyme secretion and a significant decrease of volume secretion as compared with $\mathrm{Na}$-taurodeoxycholate alone (53). The mechanism of this interaction is unknown. On the other hand, $2 \mathrm{~g}$ of chenodeoxycholate intra- 
duodenally perfused together with a Lund test meal for 30 min caused a significant increase of enzyme secretion in the subsequent 120 min as compared with the test meal alone (54). The high bile salt concentration (about $16 \mathrm{mmol} / \mathrm{l}$ ) appearing above the critical micellar concentration might have abolished a possible inhibitory effect shown for $\mathrm{Na}$ taurocholate by Malagelada et al. (49). It must be mentioned also that collection of duodenal juice was interrupted for the first 30 min during stimulation by the meal. Modifying their experimental design (15-min perfusion) in more recent studies, Koop et al., however, reported a slight inhibition $(55)$ or no change $(56,57)$ of enzyme output by addition of $2 \mathrm{~g}$ of chenodeoxycholic acid to the test meal. These controversial results have not yet been discussed by the authors.

In conscious dogs, Lueth \& Ivy (3) and Dragstedt \& Woodbury (4) noted that diversion of bile from the intestine does not influence pancreatic secretion in response to a meal. The dose-response relationship to intraduodenal $\mathrm{HCl}$, amino acids, or a liver meal was also not significantly altered by diversion and subsequent replacement of bile into the duodenum, as Konturek et al. (26) could show. Moreover, Thomas \& Crider (5) observed that the secretion of pancreatic juice after intraduodenal peptone, soap, or $\mathrm{HCl}$ is even higher when bile is diverted. Diversion of bile from the intestine increased pancreatic protein secretion after intraduodenal administration of amino acids as well. The effect could be completely reversed by intraduodenal application of taurocholate (58). Pancreatic protein output induced by intraduodenal perfusion of fat was correspondingly decreased by addition of Na-taurocholate (39). By contrast, diverting bile from the duodenum diminished pancreatic trypsin secretion stimulated by administration of a liquid meal into the stomach (59). There is no sufficient explanation for these different results.

Cholestyramine, an unabsorbable and indigestible anionexchange resin, is able to bind bile salts $(60)$. Its use provides another technique to examine the effect of endogenous bile salts on exocrine pancreatic secretion. In man, acute $(12 \mathrm{~g}$ once) and chronic ( $12 \mathrm{~g}$ three times daily for 4 weeks) ingestion of cholestyramine further increased meal-stimulated pancreatic lipase output (13). Cholestyramine perfused intraduodenally together with a test meal also caused an additional stimulation of lipase, trypsin, and amylase secretion $(54,57)$, suggesting an inhibitory effect of bile salts on luminal stimulated pancreatic secretion. Enzymes, however, were not measured during the initial $30 \mathrm{~min}$ of meal perfusion, when pancreatic response is presumably highest. In dogs, intraduodenal administration of cholestyramine also resulted in a dose-related enhancement of pancreatic protein secretion stimulated by intraduodenal application of amino acids, whereas basal pancreatic secretion was unaffected (58). This effect of cholestyramine could be completely reversed by intraduodenal administration of $\mathrm{Na}$-taurocholate.
In summary, intraduodenal bile and bile salts do not affect or even reduce pancreatic secretion stimulated by intestinal nutrient compounds in most studies performed in man and dogs, when luminal bile salt concentration is in the range of the critical micellar concentration. Under these conditions, absorption rates of fat are high, whereas pancreatic secretion is low. Luminal bile salt concentrations presumably far above the critical micellar concentration, however, slow down fat absorption rates and enhance pancreatic secretion. Bile salts also reduce phenylalanine-induced pancreatic secretion but leave absorption rates unaffected. The mode of interaction, however, seems to be mutual. Thus, intraduodenal phenylalanine significantly inhibited the hydrokinetic effect of bile salts in man. Removing bile salts from the intestine by cholestyramine further increases nutrient-stimulated pancreatic secretion, suggesting that bile salts may exert an inhibitory effect on the pancreas during digestion. The mechanisms of bile salt-nutrient compound interaction are unknown.

\section{Effect of bile and bile salts on pancreatic secretion stimulated by diversion of bile/pancreatic juice in rats}

The results obtained in rats are quite different from those in other species. Diversion of bile/pancreatic juice enhances basal pancreatic secretion $(61-66)$. The effect was continuously $(66,67)$ or transiently $(68,69)$ inhibited by intraduodenal infusion of Na-taurocholate, cholate, chenodeoxycholate, taurochenodeoxycholate, or bile (66). Only after ursodeoxycholate were a further stimulation of hydrokinetic and no influence on ecbolic pancreatic function observed (70).

Basal pancreatic volume, bicarbonate, and protein secretion obtained after diversion of pancreatic juice alone were further augmented by additional exclusion of endogenous bile from the intestine $(67,69,71)$, whereas reinfusion abolished this effect $(67,69)$. Moreover, biliary obstruction $(66,73,74)$ or exclusive diversion of bile from the intestine (66) was followed by an increase of basal pancreatic secretion. This effect could also be abolished by intraduodenal administration of taurocholate, cholate, taurochenodeoxycholate, or chenodeoxycholate. Moreover, cholestyramine feeding for a 4-week period increased both basal and CCK-stimulated pancreatic enzyme output (75) suggesting that, in rats, basal pancreatic secretion is inhibited by bile salts in the intestine.

In the Syrian golden hamster, a species related to the rat, however, bile administration exerted no inhibitory effect on pancreatic secretion. On the other hand, combined diversion of bile and pancreatic juice stimulated basal pancreatic secretion (76). Hence, one may suggest that pancreatic juice but not bile is involved in a negative feedback regulation in this species.

In summary, in the rat, exocrine pancreatic secretion stimulated by diversion of bile and/or pancreatic juice is inhibited by intraduodenal administration of various bile 
salts-with the exception of ursodeoxycholate-suggesting that interdigestive basal pancreatic secretion may be suppressed by intraduodenal bile in this species.

\section{Conclusions}

In most of the studies bile and bile salts do exert a stimulatory effect on basal or secretin/CKK-induced pancreatic secretion, as shown in Table I. On stimulation by intraluminal nutrients, however, an inhibitory action was mainly observed, confirming our hypothesis that the reciprocal effects of bile and bile salts described in the literature are primarily due to two principally different experimental designs. Further equivocal results may be explained by the relative potency of individual bile salts and, especially with regard to the rat, by species differences.

The physiologic role of bile influencing exocrine pancreatic secretion has not yet been clearly defined. In the interdigestive period intermittent gallbladder contractions are observed. Therefore, bile may stimulate exocrine pancreatic secretion and thus probably contribute to neutralization of duodenal $\mathrm{pH}$ and to 'clean the gut'. The significance of bile for the intestinal phase of pancreatic secretion is speculative because of its complex biochemical functions with regard to digestion and absorption of fat, depending on the molar concentration of bile salts. Most studies presented in the literature indicate no effect or even an inhibitory action of bile salts on pancreatic secretion. Further investigations, however, are needed with regard to the molar concentrations, the relative potencies of bile salts (with regard to basal pancreatic secretion), and the mode of meal application. The mediators involved in the action of bile on pancreatic secretion-to be discussed in another review article (43)-may also contribute to elucidation of this problem.

Rudolf L. RiePl
PETER LEHNERT
Medical Clinic
Klinikum Innenstadt
University of Munich
Munich, Germany

\section{REFERENCES}

1. Mellanby J. The secretion of pancreatic juice. J Physiol (Lond) 1926;61:419-35,

2. Ivy AC, Lueth HC. On bile stimulation of pancreatic secretion. Proc Soc Exp Biol Med 1927;24:837.

3. Lueth HC, Ivy AC. Physiology of external pancreatic secretion. JAMA 1927;89:1030.

4. Dragstedt LR, Woodbury RA. The relation of bile to the secretion of pancreatic juice. Am J Physiol 1934;107:584-8.

5. Thomas JE, Crider JO. The effect of bile in the intestine on the secretion of pancreatic juice. Am J Physiol 1943;138:548-52.

6. Lagerlöf HO. Pancreatic secretion after introduction of bile salts into the duodenum. In: Lagerlöf HO, editor. Pancreatic function and pancreatic disease. Studied by means of secretin. Acta Med Scand 1942;Suppl 128:89-91.

7. Forell MM, Stahlheber H, Scholz F. Galle als Reiz der Enzym- sekretion des Pankreas. Dtsch Med Wochenschr 1965;90:112832.

8. Forell MM, Otte M, Kohl HJ, Lehnert P, Stahlheber HP. The influence of bile and pure bile salts on pancreatic secretion in man. Scand J Gastroenterol 1971;6:261-6.

9. Wormsley KG. Stimulation of pancreatic secretion by intraduodenal infusion of bile-salts. Lancet 1970;2:586-8.

10. Osnes M, Hanssen LE, Flaten O, Myren J. Exocrine pancreatic secretion and immunoreactive secretin (IRS) release after intraduodenal instillation of bile in man. Gut 1978;19:180-4.

11. Lehnert P, Hempen I, Fiedler F, et al. Na-taurodeoxycholate acts as a specific intestinal stimulus of exocrine pancreatic secretion in man. Scand J Gastroenterol 1987;22 Suppl 139:14-9.

12. Malagelada J-R, Go VLW, DiMagno EP, Summerskill WHJ. Interactions between intraluminal bile acids and digestive products on pancreatic and gallbladder function. J Clin Invest $1973 ; 52: 2160-5$

13. Koop I, Fellgiebel A, Koop H, Schafmayer A, Arnold R. Effect of cholestyramine on plasma cholecystokinin and pancreatic polypeptide levels, and exocrine pancreatic secretion. Eur J Clin Invest 1988;18:517-23.

14. Forell MM. Bile salts as stimulants of pancreatic secretion. Proceedings of the XVIth Nobel Symposium, Stockholm 1970. In: Andersson S, editor. Frontiers in gastrointestinal hormone research. Stockholm: Almqvist \& Wiksell, 1973:277-82

15. Forell MM, Otte M, Lechelt B, et al. Einfluß der Cholezystektomie auf die exkretorische Pankreasfunktion des Menschen. Dtsch Med Wochenschr 1973;18:930-4.

16. Forell MM, Stahlheber H, Scholz F, Beitelrock H, Otte M. Die Cholecystektomie als Ursache veränderter Pankreasfunktion. Gastroenterologia 1967;107:174-8.

17. Forell MM, Stahlheber H. Gallefluß und Pankreassekretion. Klin Wochenschr 1966;44:1184-9.

18. Aronchick CA, Brooks FP. Anatomy and physiology of the biliary tract. In: Berk JE, editor. Bockus Gastroenterology. Vol. VI. 4th ed. Philadelphia: Saunders, 1985:3449-85.

19. Burhol PG, Lygren I, Waldum HL, Jorde R. The effect of duodenal infusion of bile on plasma VIP, GIP, and secretin and on duodenal bicarbonate secretion. Scand J Gastroenterol 1980;15:1007-11.

20. Otte M, Stahlheber H, Zoelch M, Forell MM. Pankreassekretion des Menschen nach Stimulation mit Cholecystokinin/Pankreozymin, Secretin und Galle. Methodik und Normalwerte. Klin Wochenschr 1973;51:915-20.

21. Osnes M, Hanssen LE, Lehnert $P$, et al. Exocrine pancreatic secretion and immunoreactive secretin release after repeated intraduodenal infusions of bile in man. Scand $\mathbf{J}$ Gastroenterol 1980;15:1033-9.

22. Osnes M, Hanssen LE. The influence of intraduodenal administration of pancreatic juice on the bile-induced pancreatic secretion and immunoreactive secretin release in man. Scand $\mathbf{J}$ Gastroenterol 1980;15:1041-7.

23. Osnes $M$. Does human bile stimulate the exocrine pancreas? Scand J Gastroenterol 1981;16:45-7.

24. Riepl RL, Lehnert $P$, Scharl A, et al. Effect of intraduodenal bile and Na-taurodeoxycholate on exocrine pancreatic secretion and on plasma levels of secretin, pancreatic polypeptide, and gastrin in man. Scand J Gastroenterol 1990;25:45-53.

25. Meyer JH, Jones RS. Canine pancreatic responses to intestinally perfused fat and products of fat digestion. Am J Physiol $1974 ; 266: 1178-87$

26. Konturek SJ, Thor P. Effect of diversion and replacement of bile on pancreatic secretion. Dig Dis Sci 1973;18:971-7.

27. Schaffalitzky de Muckadell $O B$, Fahrenkrug J, Nielsen J, Westphall $\mathrm{I}$, Worning $\mathrm{H}$. Meal-stimulated secretin release in man: effect of acid and bile. Scand J Gastroenterol 1981;16:9818.

28. Fausa $O$. Duodenal bile acids after a test meal. Scand J Gastroenterol 1974;9:567-70.

29. Erlinger S. Physiology of bile secretion and enterohepatic circulation In: Johnson LR, editor. Physiology of the gastrointestinal tract. New York: Raven Press, 1987:1557-80.

30. Björnsson OG, Fletcher DR, Christofides ND, Bloom SR, 
Chadwick VS. Duodenal perfusion with sodium taurocholate inhibits biliary but not pancreatic secretion in man. Clin Sci $1982 ; 62: 651-9$

31. Björnsson OG, Maton PN, Fletcher DR, Chadwick VS. Effects of duodenal perfusion with sodium taurocholate on biliary and pancreatic secretion in man. Eur J Clin Invest 1982;12:97-105.

32. Holtermüller KH, Dehdaschti M, Hainsch I, Herzog P, Runck A. Wirkung von Taurocholat auf die Sekretin-Caerulein stimulierte Pankreassekretion und Gallenblasenentleerung beim Menschen. Z Gastroenterol 1981;19:455

33. Eyre-Brook IA, Read NW, Brownson A, Johnson AG. Influence of intraduodenal chenodeoxycholic acid on secretory and pressure activity of the stomach and duodenum. J Gastroenterol Hepatol 1988;3:557-64.

34. Riepl RL, Kowalski C, Lehnert P, Hotz E. Der Einfluß von einzeln oder in Kombination verabreichten Gallensalzen im Duodenum auf die exokrine Pankreassekretion beim Menschen. Klin Wochenschr 1992;69 Suppl 28:155.

35. Hartmann W, Hotz J, Ormai S, Aufgebauer J, Schneider F, Goebell H. Stimulation of bile and pancreatic secretion by dudoenal perfusion with $\mathrm{Na}$-taurocholate in the cat compared with jejunal and ileal perfusion. Scand J Gastroenterol 1980; $15: 433-42$.

36. Hanssen LE, Hotz J, Hartmann W, Nehls W, Goebell H. Immunoreactive secretin release following taurocholate perfusions of the cat duodenum. Scand J Gastroenterol 1980;15:8995.

37. Gries E, Hotz J, Goebell H. Pancreatic exocrine secretion in response to intraduodenal infusion of different detergent agents in anesthetized cats. Digestion 1986;34:61-7.

38. Smallwood RA, Hoffman NE. Bile acid structure and biliary secretion of cholesterol and phospholipid in the cat, Gastroenterology 1976;71:1064-66.

39. Nustede R, Schmidt WE, Köhler H, Schafmayer A. On the relationship between plasma $C C K$ concentrations and the intraduodenal presence of bile. Digestion 1990;46:80

40. Miyasaka K, Kitani K. Effects of bile salts on pancreatic secretion in rabbits: ursodeoxycholate infused into the duodenum stimulates pancreas. Pancreas 1986;1:264-9.

41. Miyasaka K, Kitani K. The stimulatory effect of ursodeoxycholate on pancreatic secretion in the rabbit. Dig Dis Sci $1983: 28: 942$

42. IJellmann G. Der Einfluß von Gallensalzen auf die exokrine Sekretion des Pankreas beim Schwein [thesis]. Munich: University of Munich, 1970.

43. Riepl RL, Lehnert $P$. The mediators of bile action on the cxocrine pancreas [review]. Scand J Gastroenterol 1992;27. In press

44. Fiedler F, Riepl RL, Scharl A, Teufel J, Hempen I, Lehnert P. Effekt von Glyko-bzw. Taurodeoxycholat im Duodenum auf das exokrine Pankreas und die Freisetzung von GI-Peptiden. Z Gastroenterol 1989;27:557.

45. Hotz J, Hartmann W, Gries E, Klunk L, Goebell H. Stimulation of pancreatic secretion by intraduodenal bile acids: evidence of independence on intraduodenal pH. Dan Med Bull 1979;26 Suppl 1:69.

46. Frühauf $S$, Londong W, Landgraf $R$. Die exkretorische Pankreassekretion, Serumgastrin und Insulin nach intraduodenaler Bolusgabe von Kalzium beim Menschen. Z Gastroenterol 1979;5:318-34.

47. Adamczyk W. Die Pankreassekretion des Menschen nach intraduodenaler und intrajejunaler Verabreichung von Rindergalle [thesis]. Munich: University of Munich, 1973.

48. Namba $M$, Matsuyama $T$, Horie $H_{1}$ Nonaka $K$, Tarui $S$. Inhibition of pancreatic exocrine secretion and augmentation of the release of gut glucagon-like immunoreactive materials by intraileal administration of bile in the dog. Regul Pept 1983; 5:257-62

49. Malagelada J-R, DiMagno EP, Summerskill WHJ, Go VLW. Regulation of pancreatic and gallbladder functions by intraluminal fatty acids and bile acids in man. J Clin Inves 1976;58:493-9.

50. Malagelada J-R, Go VLW, DiMagno EP, Summerskill WHJ.
Interrelationships between bile acids (BA) and fatty acid (FA) absorption regulate $\mathrm{CCK}-\mathrm{PZ}$ release in man. $\mathrm{J}$ Clin Invest $1974 ; 53: 49 \mathrm{a}$.

51. Holtermüller KH, Ebner B, Herzog P, et al. Effects of duodenal (id) and jejunal (ij) perfusion of bile salts on pancreatic enzyme secretion (ps) in man: evidence for a segmental intestinal inhibition [abstract]. Scand J Gastroenterol 1982;17 Suppl 78:395.

52. Holtermüller KH, Herzog $\mathrm{P}$, Dedschati M. Effects of duodena (id) and jejunal (ij) perfusion of bile salts on pancreatic secretion and gallbladder emptying in man: a segmental intestinal inhibition. XIII Meeting of European Pancreatic Club, Academy of Medicine, Cracow, 1981:52.

53. Riepl RL, Fiedler F, Ernstberger M, Hempen I, Lehnert P. Interaction between L-phenylalanine and sodium taurodeoxycholate on exocrine pancreatic secretion. Digestion 1990;46: $171-2$

54. Koop I, Dorn S, Koop H, Gerhardt C, Arnold R. Intraduodenales Cholestyramin und Gallensäuren: Effekt aud die stimulierte Plasma-CCK-, Plasma-PP, Pankreasenzym- und Gallesekretion. Z Gastroenterol 1988;26:480.

55. Koop I, Witzleb S, Adler G, Koop H, Arnold R. Die Rolle von Cholezystokinin (CCK) in der Regulation der Pankreas- und Gallesekretion durch Gallensäuren. Z Gastroenterol 1989;27: 522

56. Koop I, Witzleb S, Lindenthal M, Adler G, Nustede R, Arnold $\mathrm{R}$. Influence of cholecystokinin (CCK) receptor blockade on bile acid-induced changes in plasma CCK, neurotensin and pancreatic enzyme output. Digestion 1990;46:58.

57. Koop I, Dorn S, Koop H, Gebhardt C, Arnold R. Intraduodenal cholestyramine and bile acids: effect on plasma-cholecystokinin (CCK), pancreatic polypeptide (PP), pancreatic and biliary secretion in man. Biomed Res 1988;9:42

58. Gomez G, Upp JR, Lluis F, et al. Regulation of the release of cholecystokinin by bile salts in dogs and humans. Gastroenterology 1988;94:1036-46.

59. Davies HA, Wheeler MH, Psaila J, et al. Bile exclusion from the duodenum. Its effect on gastric and pancreatic function in the dog. Dig Dis Sci 1985;30:954-60.

60. Grundy SM. Treatment of hypercholesterolemia by interference with bile acid metabolism. Arch Intern Med 1972; 130: 638 48

61. Fölsch UR. Fecdback regulation of pancreatic exocrine secretion in animal and man. Eur J Clin Invest 1990;20 Suppl 1:40-4.

62. Miyasaka K, Green GM. Effect of atropine on rat basal pancreatic secretion during return or diversion of bile-pancreatic juice. Proc Soc Biol Med 1983;174:187-92.

63. Shiratori K, Chen YF, Chey WY, Lec KY, Chang T-M. Mechanism of increased exocrine pancreatic sccretion in pancreatic juice-diverted rats. Gastroenterology 1986;91:1171-8.

64. Levan van H, Green GM. Effect of diversion of bile-pancreatic juice to the ileum on pancreatic secretion and adaptation in the rat. Proc Soc Exp Biol Med 1986;181:139-43.

65. Green GM, Lyman RL. Feedback regulation of pancreatic enzyme secretion as a mechanism for trypsin-inhibitor-induced hypersecretion in rats. Proc Soc Exp Biol Med 1972;140:6-12.

66. Staub VL, Sarles H. Inhibition of rat basal pancreatic secretion by intraduodenal bile. Dig Dis Sci 1979;24:602-8.

67. Kataoka K, Kashima K, Kinugasa K, et al. Effect of intraluminal bile on the feedback regulatory mechanism of pancreatic enzyme secretion in conscious rats. Gastroenterol Jpn 1985;20:234-45.

68. Ohta H, Guan D, Tawil T, Liddle RA, Green GM. Regulation of plasma cholecystokinin levels by bile and bile acids in the rat Gastroenterology 1990;99:819-25.

69. Nakamura R, Miyasaka K, Kuyama Y, Kitani K. Luminal bile regulates cholecystokinin in conscious rats. Dig Dis Sci 1990;33:53-60

70. Miyasaka K, Kitani K. A difference in stimulatory effects on pancreatic exocrine secretion between ursodeoxycholate and trypsin inhibitor in the rat. Dig Dis Sci 1986;31:978-86.

71. Nakamura R, Miyasaka K, Funakoshi A, Kitani K. Interactions between bile and pancreatic juice diversions on cholecystokinin release and pancreas in conscious rats. Proc Soc Exp Biol Med $1989 ; 192: 182-6$ 
72. Kurosawa H, Miyasaka K, Kitani K. Influence of bile flow obstruction vs bile diversion on pancreatic secretion in the conscious rat. Int J Pancreatol 1989;4:187-97.

73. Kuroyanagi $Y$, Necheles. $H$. Pancreatic secretion in the rat: effect of bile stasis and of bile salts. Am J Physiol 1962;203:60 2.

74. Geratz JD, Lamb JC. Influence of bile duct ligation on exocrine pancreatic activity in the rat. Am J Physiol 1974;227:119-22.

75. Brand SJ, Morgan RGH. Stimulation of pancreatic secretion and growth in the rat after feeding cholestyramine. Gastroenterology 1982;83:851-9.

76. Andrén-Sandberg A, Ihse I. Regulatory effects on the pancreas of intraduodenal pancreatic juice and trypsin in the Syrian golden hamster. Scand J Gastroenterol 1983;18:697-706. 